\title{
ARTICLE REVIEW: HERBS FOR COMMON COLD TREATMENT
}

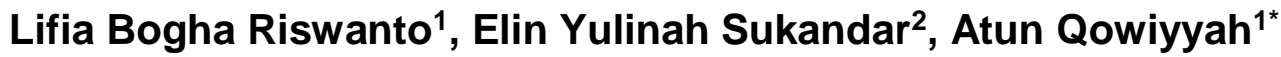

\author{
${ }^{1}$ Departement of Pharmacy, Faculty of Mathematics and Natural Sciences, \\ Universitas Garut, Jati Street No. 42B, Tarogong Kaler, Garut, West Java, 44151, \\ Indonesia \\ ${ }^{2}$ Departement of Pharmacy, Faculty of Pharmacy, Universitas Jendral Achmad \\ Yani, Terusan Jendral Sudirman Street, Cimahi, West Java, 40285, Indonesia
}

*Corresponding author: Atun Qowiyyah (atungowiyyah@gmail.com)

Received: 26 November 2021

$\frac{\text { ARTICLE HISTORY }}{\text { Revised: } 24 \text { December } 2021}$

| Accepted: 19 January 2022

\begin{abstract}
Herbs have been widely used empirically in preventing and treating diseases, one of which is a common cold. The use of herbs obtained from previous generations that are passed down orally can inhibit its development so that knowledge about traditional medicine needs to be documented and inventoried. This article review aims to examine and find out scientific information on the use of medicinal plants in treating the common cold. The research method used is a literature study obtained both offline and online such as books and original research articles published in SINTA accredited national journals and reputable international journals that have been published in the last 10 years. The results show that from the various plants used empirically, preclinical tests have been carried out. A total of 196 plants have been used empirically to treat the common cold, 5 plants have been tested for expectorant activity, 2 plants have been tested for antitussive activity, 3 plants have been tested for antipyretic activity, 3 plants have been tested for analgesic activity and 1 plant has been tested for anti-allergic activity. From several plants that have been tested for their activity, there are a total of 10 plants that have been tested for their acute toxicity. "Meniran" (Phyllanthus niruri L.) was the best herb to treat the common cold because of having proven to have expectorant, antitussive, analgesic effects and has been tested for acute toxicity test.
\end{abstract}

Key words: common cold, herbs, preclinical test, toxicity test

\section{Introduction}

People in developing countries still carry out traditional elements in living their daily lives such as using plants for the treatment of some health problems carried out by various societies and ethnicities. ${ }^{1}$ The perception of traditional medicine was formed because it was carried out from generation to generation which was trusted and believed to have efficacy and safety. ${ }^{2}$ Knowledge of the use of traditional medicine that is passed down orally can hinder its development so it needs to be documented and inventoried. Numerous ways can be done to maintain this knowledge of traditional medicine for example by conducting interviews with traditional healers. Documentation of knowledge 
about traditional medicine that used empirically could be found in books such as "Cabe Puyang Warisan Nenek Moyang", "Tanaman Obat Indonesia", "Obat Asli Indonesia", as well as monograph books such as "Materia Medika Indonesia", also publications in various seminars proceeding and journals. From those various books, data were obtained in the form of the name of the plant area, the Latin name of the plant and the part of the plant that was used empirically, while in the book "Obat Asli Indonesia" obtained data in the form of how to make traditional medicine.

Herbs or medicinal plants are widely used in the treatment of various diseases in Indonesia. Modernization in today's society possibly treats the legacy of traditional medicine. This fact encourages efforts to preserve the knowledge of traditional medicine with an ethnopharmaceutical approach. ${ }^{3}$ The ethnopharmaceutical study is a scientific approach method that can assist the process of deepening cultural knowledge about traditional recipes for the treatment of a disease. ${ }^{4}$

The common cold is an acute and self-limited infectious disease caused by viruses that attack the upper respiratory tract which symptoms such as cough, fever, rhinorrhea, stuffy nose, dizziness, etc. The infection may also affect lower respiratory tract. ${ }^{5,6}$ Colds are characterized by sore throat, malaise and mild fever at first. These symptoms resolved within a few days and were followed by nasal congestion, runny nose and cough within 1-2 days of the onset of the first symptoms. The second set of symptoms is the cause that make most patients seek medical attention for relief. Symptoms typically peak around day 3 or 4 and begin to resolve by day 7. Runny nose present as a peak of common cold, may become thick and purulent and may misdiagnosed as bacterial sinus infection. ${ }^{7}$ Basic Health Research on 2018 shows that the prevalence of colds in Indonesia by province is $4.4 \%$ or in the range of $4.3 \%-4.5 \%$, while in toddlers is $7.5 \%$ or in the range of $7.5 \%-8.2 \% .^{8}$

Common cold therapy can be done pharmacologically and non-pharmacologically. Antiviral agents were ineffective in common cold treatment, so that pharmacological therapy in the management of common cold is symptomatic therapy with the administration of analgesic-antipyretic drugs, antihistamines, decongestants, antitussives, or expectorants. ${ }^{5,6}$ Alternative treatment using herbs on common cold has been increasing due to less side effect compared to synthetic drugs. ${ }^{9}$

Some of the herbs used empirically to treat colds were "sembung" (Blumea balsimifera L.), "pecut kuda" (Stachytarpheta jamaicensis L.), "belimbing wuluh" (Averrhoa bilimbi L.), "kapok" (Ceiba pentandra Gaertn), lime (Citrus aurantifolia (Christm.) Swingle), quinine (Cinchona sp.), ginger (Zingiber officinale Rosc.), papaya (Carica papaya L.), "meniran" (Phyllanthus niruri L.), rosella (Hibiscus sabdariffa L.), "takokak" (Solanum torvum Swartz.), basil (Ocimum sanctum L.), etc. ${ }^{10-14}$ Some of these plants besides being used empirically in treating colds, are also used in treating various diseases. Papaya were used to treat wounds, digestive agent, cancerous tumors; the seeds are used as a gentle purgative for worms; the flowers may be taken in an infusion to induce menstruation; and a decoction of the ripe fruit is helpful for treating persistent diarrhea and dysentery in children; while the ripe fruit is mildly laxative and the leaves are used to dress wounds. ${ }^{15,16}$ Rosella is used for anti-hyperuricemia, "pecut kuda" is used to treat tonsilitis etc. ${ }^{15}$ Ginger has been used to treat respiratory disorder such as cough, influenza, antiviral, antiemetic, digestive stimulant, headache and migraine, joint pain, motion sickness and indigestion disorder such as stomach ache, vomiting, diarrhea, etc. ${ }^{17,16}$ Basil has been used to reduce blood sugar levels, helps lower blood pressure and has anti-inflammatory, analgesic, pain-relieving and fever-reducing properties, adaptogenic, anticancer properties, protects against radiation; the herbs strengthens immune resistance and inhibits sperm production. ${ }^{16}$

In this review, a literature study of herbs pharmacological activities related to the management of common cold is conducted based on empirical data on the use of 
medicinal plants in various reference. This article review aims to examine and find out scientific information include preclinical and clinical trial of medicinal plants that used in treating common cold empirically. The benefits of this article review are as a source of information for further research, as reference material for drug industries, providing information to the public on the use of medicinal plants and alternative therapies from natural ingredients to deal with colds and can develop the use of medicinal plants in Indonesia. From this review article, it can be concluded the best herb in treating common cold supported by preclinical and clinical data (if any) that derived from empirical use in Indonesia.

\section{Method}

The method used in this review is a literature study. The references used are articles published in SINTA accredited national journals and reputable international journals published in the last 10 years. Library searches were carried out offline and online. Offline references are obtained from various books such as "Cabe Puyang Warisan Nenek Moyang", "Tanaman Obat Indonesia", "Obat Asli Indonesia", as well as monograph books such as "Farmakope Herbal Indonesia" related to herbs handling of common cold so that various plant information is obtained that is used empirically in the treatment of cough and cold. Online references were obtained through Google Scholar, Elsevier, PubMed, and Science Direct. The herbs data obtained from empirical study are then searched for preclinical tests (pharmacological activity, toxicity tests) and clinical trial and compiled into a review article. The stages are carried out by determining the theme of the article, determining the title of the article, looking for medicinal plants that are efficacious in books containing empirical use or from several ethnopharmacology journals, searching for literature related to pharmacological activities and toxicity tests.

The obtained reference are grouped into main references and supporting references, screening and scanning the obtained references. The main references used are book that contains empirical uses of herbs such as "Cabe Puyang Warisan Nenek Moyang", "Tanaman Obat Indonesia", "Obat Asli Indonesia", several ethnopharmacology journal and literature related to pharmacological activities and toxicity tests. The supporting reference used monograph books such as "Farmakope Herbal Indonesia" and "Materia Medika Indonesia". Some of the data obtained were used in the preparation of review articles such as the method used, the plant and species name the comparison drug, the induction method, results of preclinical tests in the form of pharmacological activities and toxicity tests.

\section{Result}

Based on the results of a literature study on herbs for treating colds, it was found that 196 plants were used empirically to treat colds. A total of 27 plants were obtained from "Cabe Puyang Warisan Nenek Moyang", 57 plants were obtained from "Tanaman Obat Indonesia", 92 plants were obtained from "Obat Asli Indonesia", there were 12 plants listed for their empirical use in the three books previously mentioned and 8 plants obtained from online literature, while monographs book were used to find out empirical uses and secondary metabolite contained in plants. In the "Materia Medika Indonesia", no herbs found in treatment of common cold.

$A$ total of 12 plants have been tested for pharmacological activities related to colds such as expectorant, antitussive, antipyretic, analgesic, and anti-allergic activities. A total of 10 plants have been tested for their toxicity in the form of acute toxicity, where the toxicity test obtained was limited to acute toxicity tests. All the information presented in the table of pharmacological activity tests and toxicity test are obtained from the online 
literature based on empirical use of plants. So far only preclinical trial of these herbs have been carried out, while the results of clinical trial have not been found.

A total of 5 plants were tested for expectorant activity (mucolytic and secretolytic) consisting of basil (Ocimum sanctum L.), red betel (Piper crocatum Ruiz and Pav), rosella (Hibiscus sabdariffa L.), "miana" (Coleus scutellarioides (L.) Benth) and "meniran" (Phyllanthus niruri L.).

Table 1. Expectorant Activity of Some Plants

\begin{tabular}{|c|c|c|c|c|c|c|c|}
\hline \multirow{2}{*}{$\begin{array}{l}\text { Name and } \\
\text { part of the } \\
\text { plants }\end{array}$} & \multirow{2}{*}{$\begin{array}{l}\text { Extracting } \\
\text { solvent }\end{array}$} & \multirow{2}{*}{$\begin{array}{l}\text { Compound } \\
\text { content }\end{array}$} & \multirow{2}{*}{$\begin{array}{l}\text { Concentration/ } \\
\text { effective dose }\end{array}$} & \multirow{2}{*}{ Method } & \multicolumn{2}{|c|}{$\begin{array}{c}\text { Decrease in viscosity } \\
(\%)\end{array}$} & \multirow{2}{*}{ Reference } \\
\hline & & & & & Extract & Comparison & \\
\hline $\begin{array}{l}\text { Basil leaves } \\
\text { (Ocimum } \\
\text { sanctum L.) }\end{array}$ & Ethanol & \multirow{3}{*}{$\begin{array}{l}\text { Alkaloids, } \\
\text { flavonoids, } \\
\text { saponins, } \\
\text { tannins, and } \\
\text { steroids or } \\
\text { triterpenoids. }\end{array}$} & $0.5 \%$ & $\begin{array}{l}\text { In vitro } \\
\text { using cow } \\
\text { intestinal } \\
\text { mucus }\end{array}$ & 38.71 & \multirow{3}{*}{$\begin{array}{c}52.71 \\
\text { (Acetylcysteine } \\
0.1 \% \text { ) }\end{array}$} & \multirow{3}{*}{ (18) } \\
\hline $\begin{array}{l}\text { Red betel } \\
\text { leaves (Piper } \\
\text { crocatum Ruiz } \\
\text { and Pav) }\end{array}$ & Ethanol & & $0.5 \%$ & $\begin{array}{l}\text { In vitro } \\
\text { using cow } \\
\text { intestinal } \\
\text { mucus }\end{array}$ & 36.77 & & \\
\hline $\begin{array}{l}\text { Combination } \\
\text { of basil leaves } \\
\text { (Ocimum } \\
\text { sanctum L.) } \\
\text { and red betel } \\
\text { leaves (Piper } \\
\text { crocatum Ruiz } \\
\text { and Pav) }\end{array}$ & Ethanol & & $0.5 \%$ and $0.5 \%$ & $\begin{array}{l}\text { In vitro } \\
\text { using cow } \\
\text { intestinal } \\
\text { mucus }\end{array}$ & 25.10 & & \\
\hline \multirow{2}{*}{$\begin{array}{l}\text { Rosella flower } \\
\text { petals } \\
\text { (Hibiscus } \\
\text { sabdariffa L.) }\end{array}$} & $\begin{array}{l}\text { Ethyl } \\
\text { acetate }\end{array}$ & \multirow{2}{*}{$\begin{array}{l}\text { Alkaloids, } \\
\text { flavonoids, } \\
\text { saponins, } \\
\text { glycosides, } \\
\text { and tannins. }\end{array}$} & $0.8 \%$ & \multirow{2}{*}{$\begin{array}{l}\text { In vitro } \\
\text { using cow } \\
\text { intestinal } \\
\text { mucus }\end{array}$} & 75.89 & \multirow{2}{*}{$\begin{array}{c}76.44 \\
\text { (Acetylcysteine } \\
0.1 \% \text { ) }\end{array}$} & \multirow{2}{*}{ (19) } \\
\hline & Methanol & & $0.6 \%$ & & 75.87 & & \\
\hline $\begin{array}{l}\text { Miana leaves } \\
\text { (Coleus } \\
\text { scutellarioides } \\
\text { (L.) Benth) }\end{array}$ & Aquadest & $\begin{array}{l}\text { Flavonoids, } \\
\text { saponins, } \\
\text { tannins, } \\
\text { terpenoids, } \\
\text { and } \\
\text { essential } \\
\text { oils. }\end{array}$ & $1.75 \%$ & $\begin{array}{l}\text { In vitro } \\
\text { using a } \\
\text { mixture of } \\
\text { mucus } \\
\text { from } \\
\text { patients } \\
\text { with non- } \\
\text { acute } \\
\text { cough and } \\
\text { cow } \\
\text { intestine } \\
\text { mucus }\end{array}$ & 39.27 & $\begin{array}{c}39.80 \\
\text { (Bromhexine } \\
0.05 \% \text { ) }\end{array}$ & (20) \\
\hline $\begin{array}{l}\text { Meniran herbs } \\
\text { (Phyllanthus } \\
\text { niruri L.) }\end{array}$ & $\begin{array}{l}\text { Polar - } \\
\text { semi polar } \\
\text { fraction ( } \mathrm{n}- \\
\text { hexane - } \\
\text { ethyl } \\
\text { acetate - } \\
\text { ethanol) } \\
\end{array}$ & $\begin{array}{l}\text { Quercetin, } \\
\text { lupeol. }\end{array}$ & $80 \mathrm{mg} / \mathrm{kgBW}$ & $\begin{array}{l}\text { In vivo } \\
\text { with } 7.5 \% \\
\text { citric acid } \\
\text { induction }\end{array}$ & 56.91 & $\begin{array}{l}64.98 \text { (Glyceryl } \\
\text { guaiacolat) }\end{array}$ & $(21)$ \\
\hline
\end{tabular}

A total of 2 plants were tested for antitussive activity consisting "takokak" (Solanum torvum Swartz) and "meniran" (Phyllanthus niruri L.). 
Table 2. Antitussive Activity of Some Plants

\begin{tabular}{|c|c|c|c|c|c|c|c|}
\hline $\begin{array}{l}\text { Name and } \\
\text { part of } \\
\text { the plants }\end{array}$ & $\begin{array}{l}\text { Extracting } \\
\text { solvent }\end{array}$ & $\begin{array}{l}\text { Compound } \\
\text { content }\end{array}$ & $\begin{array}{l}\text { Effective } \\
\text { dose }\end{array}$ & Method & $\begin{array}{l}\text { \% Cough } \\
\text { suppression } \\
\text { extract }\end{array}$ & $\begin{array}{l}\% \text { Comparative } \\
\text { cough } \\
\text { suppression }\end{array}$ & Reference \\
\hline $\begin{array}{l}\text { Takokak } \\
\text { leaves } \\
\text { (Solanum } \\
\text { torvum L.) }\end{array}$ & Methanol & $\begin{array}{l}\text { Tannins, } \\
\text { flavonoids, } \\
\text { saponins, } \\
\text { alkaloids, } \\
\text { and } \\
\text { glycosides. }\end{array}$ & $\begin{array}{l}1000 \\
\mathrm{mg} / \mathrm{kgBW}\end{array}$ & $\begin{array}{l}\text { In vivo by } \\
\text { citric acid } \\
\text { induction }\end{array}$ & 38.71 & $\begin{array}{l}76.20 \\
\text { (Dihydrocodeine } \\
20 \mathrm{mg} / \mathrm{kgBW} \text { ) }\end{array}$ & (22) \\
\hline $\begin{array}{l}\text { Meniran } \\
\text { herb } \\
\text { (Phyllanth } \\
\text { us niruri } \\
\text { L.) }\end{array}$ & $\begin{array}{l}\text { Polar - } \\
\text { semi polar } \\
\text { fraction ( } n- \\
\text { hexane - } \\
\text { ethyl } \\
\text { acetate - } \\
\text { ethanol) }\end{array}$ & $\begin{array}{l}\text { Quercetin, } \\
\text { astragalin, } \\
\text { and xylan. }\end{array}$ & $\begin{array}{l}80 \\
\mathrm{mg} / \mathrm{kgBW}\end{array}$ & $\begin{array}{l}\text { In vivo } \\
\text { with } \\
7.5 \% \\
\text { citric acid } \\
\text { induction }\end{array}$ & 56.91 & $\begin{array}{l}71.67 \text { (Codeine } \\
10 \mathrm{mg} / \mathrm{kgBW})\end{array}$ & (21) \\
\hline
\end{tabular}

Several plants have been tested for antipyretics activity, namely "belimbing wuluh" (Averrhoa bilimbi L.), "wualae" (Etlingera elatior (Jack) R. M. Smith), and basil (Ocimum basilicum L.) using diphtheria pertussis tetanus (DPT) vaccine and peptone as a fever inductor.

Table 3. Antipyretics Activity of Some Plants

\begin{tabular}{|c|c|c|c|c|c|c|c|}
\hline $\begin{array}{l}\text { Name } \\
\text { and part } \\
\text { of the } \\
\text { plants }\end{array}$ & $\begin{array}{l}\text { Extracting } \\
\text { solvent }\end{array}$ & $\begin{array}{l}\text { Compound } \\
\text { content }\end{array}$ & $\begin{array}{l}\text { Concentration/ } \\
\text { effective dose }\end{array}$ & Method & $\begin{array}{c}\text { Decrease in } \\
\text { body } \\
\text { temperature } \\
\text { extract (\%) }\end{array}$ & $\begin{array}{l}\text { Decrease in } \\
\text { body } \\
\text { temperature of } \\
\text { comparison } \\
(\%)\end{array}$ & Reference \\
\hline $\begin{array}{l}\text { Belimbing } \\
\text { wuluh } \\
\text { fruit } \\
\text { (Averrhoa } \\
\text { bilimbi L.) }\end{array}$ & Ethanol & $\begin{array}{l}\text { Alkaloids, } \\
\text { flavonoids } \\
\text { and } \\
\text { saponins. }\end{array}$ & $1.75 \mathrm{~g} / \mathrm{kgBW}$ & $\begin{array}{l}\text { In vivo by } \\
\text { induction } \\
\text { of } \\
\text { diphtheria } \\
\text { pertussis } \\
\text { tetanus } \\
\text { (DPT) } \\
\text { vaccine }\end{array}$ & 22.9 & $\begin{array}{l}27.8 \text { (Aspirin } \\
0.004 \\
\mathrm{~g} / \mathrm{kgBW})\end{array}$ & (23) \\
\hline $\begin{array}{l}\text { Wualae } \\
\text { fruit } \\
\text { (Etlingera } \\
\text { elatior } \\
\text { (Jack) R. } \\
\text { M. Smith) }\end{array}$ & Ethanol & $\begin{array}{l}\text { Polyphenols, } \\
\text { alkaloids, } \\
\text { flavonoids } \\
\text { (Quercetin), } \\
\text { saponins } \\
\text { and } \\
\text { essential } \\
\text { oils. }\end{array}$ & $400 \mathrm{mg} / \mathrm{kgBW}$ & $\begin{array}{l}\text { In vivo by } \\
\text { induction } \\
\text { of } \\
\text { diphtheria } \\
\text { pertussis } \\
\text { tetanus } \\
\text { (DPT) } \\
\text { vaccine }\end{array}$ & 90 & $\begin{array}{l}95.9 \\
\text { (Paracetamol } \\
1.3 \\
\mathrm{mg} / \mathrm{kgBW})\end{array}$ & (24) \\
\hline $\begin{array}{l}\text { Basil } \\
\text { seeds } \\
\text { (Ocimum } \\
\text { basilicum } \\
\text { L.) }\end{array}$ & $\begin{array}{l}\text { Ethyl } \\
\text { acetate }\end{array}$ & Flavonoids & $10 \%$ & $\begin{array}{l}\text { In vivo with } \\
12.5 \% \\
\text { peptone } \\
\text { induction }\end{array}$ & 88.23 & $\begin{array}{l}91.9 \\
\text { (Paracetamol } \\
2 \mathrm{mg} / 3 \\
\mathrm{kgBW})\end{array}$ & (25) \\
\hline
\end{tabular}


A total of 3 plants were tested for analgetic activity consisting "meniran" (Phyllanthus niruri L.), "sembukan" (Paederia foetida L.), and papaya (Carica papaya L.).

Table 4. Analgesics Activity of Some Plants

\begin{tabular}{|c|c|c|c|c|c|c|c|}
\hline $\begin{array}{l}\text { Name and } \\
\text { part of the } \\
\text { plants }\end{array}$ & $\begin{array}{l}\text { Extracting } \\
\text { solvent }\end{array}$ & $\begin{array}{l}\text { Compound } \\
\text { content }\end{array}$ & $\begin{array}{l}\text { Concentration/ } \\
\text { effective dose }\end{array}$ & Method & $\begin{array}{c}\text { Extract } \\
\text { protection } \\
\text { power (\%) }\end{array}$ & $\begin{array}{l}\text { Comparator } \\
\text { protection } \\
\text { power (\%) }\end{array}$ & Reference \\
\hline $\begin{array}{l}\text { Meniran } \\
\text { leaves } \\
\text { (Phyllantus } \\
\text { niruri L.) }\end{array}$ & Ethanol & $\begin{array}{l}\text { Alkaloids } \\
\text { (securinins), } \\
\text { flavonoids } \\
\text { (quercetin, } \\
\text { quercitrin, } \\
\text { isoquercitrin, } \\
\text { astragalin, } \\
\text { nirunine, } \\
\text { niruside, } \\
\text { routine, } \\
\text { leucodelfinidin, } \\
\text { and } \\
\text { galacotekin). }\end{array}$ & $100 \mathrm{mg} / \mathrm{kgBW}$ & $\begin{array}{l}\text { In vivo } \\
\text { with } 1 \% \\
\text { acetic } \\
\text { acid } \\
\text { induction }\end{array}$ & 73.56 & $\begin{array}{l}76.82 \\
\text { (ibuprofen } \\
400 \\
\mathrm{mg} / \mathrm{kgBW} \text { ) }\end{array}$ & (26) \\
\hline $\begin{array}{l}\text { Sembukan } \\
\text { herbs } \\
\text { (Paederia } \\
\text { foetida L.) }\end{array}$ & Ethanol & $\begin{array}{l}\text { Flavonoids, } \\
\text { tannins, } \\
\text { saponins, and } \\
\text { steroids. }\end{array}$ & $320 \mathrm{mg} / \mathrm{kgBW}$ & $\begin{array}{l}\text { In vivo } \\
\text { with } 0.5 \% \\
\text { acetic } \\
\text { acid } \\
\text { induction }\end{array}$ & 68.98 & $\begin{array}{l}39.18 \\
\text { (Diclofenac } \\
\text { potassium) }\end{array}$ & $(27)$ \\
\hline $\begin{array}{l}\text { Papaya } \\
\text { leaves } \\
\text { (Carica } \\
\text { papaya L.) }\end{array}$ & Ethanol & Flavonoids & $600 \mathrm{mg} / \mathrm{kgBW}$ & $\begin{array}{l}\text { In vivo } \\
\text { with } 1 \% \\
\text { acetic } \\
\text { acid } \\
\text { induction }\end{array}$ & 59.94 & $\begin{array}{l}80 \\
\text { (Paracetamol } \\
65 \mathrm{mg} / \mathrm{kgBW})\end{array}$ & (28) \\
\hline
\end{tabular}

Guava (Psidium guajava L.) is a plant belongs to Myrtaceae family. Guava plant parts are widely used both as food and medical plants. Empirically used as an antioxidant, antitumor, anti-inflammatory, anti-allergic, and so on.

Table 5. Anti-allergic Activity of Some Plants

\begin{tabular}{|c|c|c|c|c|c|c|c|}
\hline $\begin{array}{l}\text { Name and } \\
\text { part of the } \\
\text { plants }\end{array}$ & $\begin{array}{l}\text { Extractin } \\
\text { g solvent }\end{array}$ & $\begin{array}{l}\text { Compound } \\
\text { content }\end{array}$ & $\begin{array}{l}\text { Effective } \\
\text { dose }\end{array}$ & Method & $\begin{array}{l}\text { The average } \\
\text { number of } \\
\text { scratch } \\
\text { from extract }\end{array}$ & $\begin{array}{l}\text { The average } \\
\text { number of } \\
\text { comparison } \\
\text { drug }\end{array}$ & Reference \\
\hline $\begin{array}{l}\text { Guava } \\
\text { leaves } \\
\text { (Psidium } \\
\text { guajava) }\end{array}$ & Ethanol & $\begin{array}{l}\text { Flavonoids } \\
\text { (quercetin) }\end{array}$ & $\begin{array}{c}54 \\
\mathrm{mg} / 200 \mathrm{gB} \\
\mathrm{W}\end{array}$ & $\begin{array}{l}\text { In vivo by } \\
\text { induction } \\
\text { of } 0.1 \% \\
\text { ovalbumin } \\
\text { suspensio } \\
n\end{array}$ & 9.00 & $\begin{array}{l}12.25 \\
\text { (Methylprednis } \\
\text { olone } 0.072 \\
\mathrm{mg} / 200 \mathrm{gBW} \text { ) }\end{array}$ & (29) \\
\hline
\end{tabular}

A total of 10 plants have been tested for their acute toxicity using various methods from 12 plants that have been tested pre-clinically. The long-term toxicity test of these herbs have not been found such as sub-chronic and chronic toxicity test. 
Table 6. Toxicity Test of Some Plants

\begin{tabular}{|c|c|c|c|c|c|c|}
\hline $\begin{array}{l}\text { Plant } \\
\text { name }\end{array}$ & $\begin{array}{l}\text { Plant } \\
\text { parts }\end{array}$ & Solvent & Method & $\begin{array}{l}\text { Type of } \\
\text { toxicity }\end{array}$ & $\begin{array}{l}\text { Toxicity test } \\
\text { value }\end{array}$ & Reference \\
\hline $\begin{array}{l}\text { Basil } \\
\text { (Ocimum } \\
\text { sanctum } \\
\text { L.) }\end{array}$ & Leaves & Ethanol & $\begin{array}{l}\text { OECD } 420 \text { fix } \\
\text { dose procedure }\end{array}$ & Acute & $\begin{array}{l}\mathrm{LD}_{50}>2000 \\
\mathrm{mg} / \mathrm{kgBW}\end{array}$ & (30) \\
\hline $\begin{array}{l}\text { Rosella } \\
\text { (Hibiscus } \\
\text { sabdariffa } \\
\text { L.) }\end{array}$ & $\begin{array}{l}\text { Flower } \\
\text { petals }\end{array}$ & Ethanol & Conventional & Acute & $\begin{array}{l}\mathrm{LD}_{50}= \\
850.90 \\
\mathrm{mg} / \mathrm{kgBW}\end{array}$ & (31) \\
\hline $\begin{array}{l}\text { Miana } \\
\text { (Coleus } \\
\text { scutellarioi } \\
\text { des (L.) } \\
\text { Benth) } \\
\end{array}$ & Leaves & Ethanol & - & Acute & $\begin{array}{l}L_{50}= \\
9757.14 \\
\mathrm{mg} / \mathrm{kgBW}\end{array}$ & (32) \\
\hline $\begin{array}{l}\text { Meniran } \\
\text { (Phyllanthu } \\
\text { s niruri L.) }\end{array}$ & Leaves & Aquadest & - & Acute & $\begin{array}{l}\mathrm{LD}_{50}>5000 \\
\mathrm{mg} / \mathrm{kgBW}\end{array}$ & (33) \\
\hline $\begin{array}{l}\text { Takokak } \\
\text { (Solanum } \\
\text { torvum } \\
\text { Swartz.) }\end{array}$ & Leaves & $\begin{array}{l}\text { Hydro- } \\
\text { alcohol }\end{array}$ & Miller and Trainer & Acute & $\begin{array}{l}\mathrm{LD}_{50}>2000 \\
\mathrm{mg} / \mathrm{kgBW}\end{array}$ & (34) \\
\hline $\begin{array}{l}\text { Wualae } \\
\text { (Etlingera } \\
\text { elatior } \\
\text { (Jack) R. } \\
\text { M. Smith) }\end{array}$ & Fruits & Ethanol & Reed-Munch & Acute & $\begin{array}{l}\mathrm{LD}_{50}= \\
8649.679 \\
\mathrm{mg} / \mathrm{kgBW} \\
\text { (practically } \\
\text { non-toxic) }\end{array}$ & (35) \\
\hline $\begin{array}{l}\text { Basil } \\
\text { (Ocimum } \\
\text { basilicum } \\
\text { L.) }\end{array}$ & Seeds & $\begin{array}{l}\text { Basil seed } \\
\text { hydrogel }\end{array}$ & $\begin{array}{l}\text { OECD } 420 \text { fix } \\
\text { dose procedure }\end{array}$ & Acute & $\begin{array}{l}\mathrm{LD}_{50}=9000 \\
\mathrm{mg} / \mathrm{kgBW}\end{array}$ & (36) \\
\hline $\begin{array}{l}\text { Sembukan } \\
\text { (Paederia } \\
\text { foetida L.) }\end{array}$ & Leaves & Ethanol & OECD 423 & Acute & $\begin{array}{c}\mathrm{LD}_{50}>2000 \\
-5000 \\
\mathrm{mg} / \mathrm{kgBW}\end{array}$ & (37) \\
\hline $\begin{array}{l}\text { Papaya } \\
\text { (Carica } \\
\text { papaya L.) }\end{array}$ & Leaves & $\begin{array}{l}\text { Methanol } \\
\text { n-Hexane }\end{array}$ & - & Acute & $\begin{array}{c}\mathrm{LD}_{50}>1000 \\
\mathrm{mg} / \mathrm{kgBW}\end{array}$ & (38) \\
\hline $\begin{array}{l}\text { Guava } \\
\text { (Psidium } \\
\text { guajava) }\end{array}$ & Leaves & Aquadest & - & Acute & $\begin{array}{c}\mathrm{LD}_{50}>5000 \\
\mathrm{mg} / \mathrm{kgBW}\end{array}$ & (39) \\
\hline
\end{tabular}

\section{Discussion}

Common cold is a self-limited disease caused by various viruses that don't produce lasting immunity after infection such as respiratory syncytial virus, para-influenza virus, and human coronavirus; meanwhile viruses that produce lasting immunity such as 
rhinovirus, adenovirus, influenza virus, and enterovirus. The release of cytokines and other inflammatory mediators from infected nasal epithelial cells and from an influx of polymorphonuclear cells could result various symptom of common cold such as fever (more common on children and infant), sore and scratchy throat, rhinorrhea, cough, sneeze, malaise, sinus fullness, and hoarseness. Treatment for common cold may be aimed to interrupt the release of inflammatory mediators and reduce the symptoms of common cold. ${ }^{6}$

Antibacterial or antiviral agents are not recommended to treat colds in children or adults. Other choice of drug can be used to relieve some symptoms. Antitussives such as dextromethorphan is a treatment option for adults with coughs as well as older firstgeneration antihistamines and combination antihistamines/decongestants if the benefits outweigh the adverse effects. Topical or oral decongestants used for up to three days are a treatment option for adolescents and adults. Topical ipratropium is a treatment option for stuffy nose in children over six years of age and adults although it is expensive. Among the complementary treatments currently available vitamin $\mathrm{C}$ prophylaxis can reduce the severity and duration of cold symptoms; however vitamin $\mathrm{C}$, zinc, and Echinacea are not recommended for aggressive treatment. ${ }^{9}$

Herbs used as an alternative to the common cold treatment are those that have been tested for their pharmacological activities related to symptom arise such as expectorants, antitussive, antihistamine, decongestant, analgesic-antipyretic, etc.

\section{Expectorant Activity}

1. Basil (Ocimum sanctum L.) is a plant belonging to the Lamiaceae family, while red betel (Piper crocatum Ruiz and Pav) belongs to the Piperaceae family. The expectorant activity testing on ethanol extract of basil leaves, red betel leaves, and the combination of both was carried out using the in vitro method by measuring the viscosity of mucus from cows intestinal mucosa. The percentage decrease in viscosity is obtained by calculating the difference of viscosity before and after treatment divided by the initial viscosity multiplied by $100 \%$. The comparison drug was $0.1 \%$ acetylcysteine which showed a significant decrease in viscosity $(p<0.05)$ compared to the control group, with a decrease in viscosity of $52.71 \%$. While the results of the mucolytic activity test on each extract showed that the combination of $0.5 \%$ basil leaves ethanol extract and $0.5 \%$ red betel leaves had greater mucolytic activity compared to single extract preparations with a decrease in viscosity of $25.10 \%$ because it showed a significant difference $(p<0.05)$ against the control with almost the same effect as the comparison. The combination of these plants has a synergistic effect that can increase mucolytic activity. This is presumably due to the content of secondary metabolites, namely saponins, alkaloids and flavonoids. Saponin compounds can stimulate the secretion of bronchial secretions, increase the activation of the ciliary epithelium so that it can expel phlegm when coughing occurs. Alkaloid compounds work by inhibiting the formation of bacterial cell peptidoglycan so that the bacterial cell layer is not formed. Flavonoid compounds work by breaking down mucoprotein threads and mucus mucopolysaccharides while tannins work by inhibiting cell permeability. ${ }^{18}$ The acute toxicity test of Basil leaves was carried out using the OECD 420 fix dose procedure method and the LD $_{50}$ value was $>2000 \mathrm{mg} / \mathrm{kgBW}$ and is included in the category of mild toxic. ${ }^{30}$

2. Rosella is a plant that belongs to the Malvaceae family. Rosella flower petal extract was made using different solvents consisting of a non-polar solvent in the form of $n$ hexane, semi-polar in the form of ethyl acetate, and a polar solvent in the form of methanol which was macerated 2 times to obtain a thick extract. The mucolytic activity test was carried out by testing the extract of flower petals with various solvents used on the intestinal mucosa of cows. The test results of $n$-hexane extract 
of rosella flower petals did not show or did not work stronger as a mucolytic than the positive control. The ethyl acetate extract of rosella petals at a dose of $0.8 \%$ and a dose of $0.6 \%$ of the methanol extract of rosella petals showed mucolytic activity which was comparable to the positive control given $0.1 \%$ acetylcysteine. Ethyl acetate extract $0.8 \%$ rosella petals gave a decrease in viscosity of $75.89 \%$ while methanol extract $0.6 \%$ gave a decrease in viscosity of $75.87 \%$ which was almost comparable to a decrease in viscosity of $0.1 \%$ acetylcysteine, which was $76.44 \% .^{19}$ The toxicity of rosella petals was tested using conventional methods and the $\mathrm{LD}_{50}$ value was $850.90 \mathrm{mg} / \mathrm{kgBW}$ and is included in the category of mild toxic. ${ }^{31}$

3. "Miana" is a plant that belongs to the Lamiaceae family and is empirically used to treat coughs. The test was carried out using freeze-dried aqueous extract of "miana" (Coleus scutellarioides (L.) Benth) leaves and tested for their mucolytic activity using the same method as the previous species. The dry extract was diluted in the range of $0.01 \%-2.5 \%$ and tested on the intestinal mucosa of cattle. "Miana" leaves water extract at concentration of $1.75 \% \mathrm{w} / \mathrm{v}$ showed the most effective dose in reducing the viscosity of the intestinal mucosa of cattle. This fact proves that the aqueous extract of "miana" leaves at concentration of $1.75 \% \mathrm{w} / \mathrm{v}$ has expectorant activity not significantly different from $0.05 \%$ Bromhexine $(p<0.05)$. The decrease in the viscosity of the extract was $39.27 \%$ while the positive control was $64.98 \%$ which showed no significant difference in reducing the viscosity. The compound content of "miana" leaves consists of flavonoids, tannins, terpenoids, saponins, and quinone derivatives. It supposed that saponins contain surfactants act as mucolytic by lower the surface tension of mucus. ${ }^{20}$ The toxicity testing of "miana" leaves was carried out in vivo with ethanol solvent and the LD $_{50}$ value was $9757.14 \mathrm{mg} / \mathrm{kgBW}$ and is included in the category of practically non-toxic. ${ }^{32}$

4. "Meniran" (Phyllanthus niruri L.) is a plant that belongs to Phyllanthaceae family. "Meniran" herb testing was carried out using the in vivo method to determine the expectorant activity given citric acid induction in male guinea pigs. Phenol red was given to color the trachea in the test animals and then the trachea was isolated to produce a tracheal extract whose absorbance would be measured. Tracheal phenol red concentrations in the ethanol extract group of 124 and $250 \mathrm{mg} / \mathrm{kgBW}$ and the polar-semi-polar fraction $160 \mathrm{mg} / \mathrm{kgBW}$ did not significantly suppress mucus secretion. While the polar-semi-polar fraction of "meniran" herbs at a dose of 80 $\mathrm{mg} / \mathrm{kgBW}$ showed a significant decrease in tracheal phenol red levels $(p<0.05)$ compared to the control group which gave $56.91 \%$ suppression effect of mucus secretion while the effect of suppression of mucus secretion on comparison of $64.98 \%$. This is because, at that dose, it provides tracheal mucus suppression activity in guinea pigs. Several compounds contained in "meniran" herbs can inhibit the production of cytokines so that they will provide activity in inhibiting mucin secretion. Another literature states that lupeol works by suppressing mucus secretion so that it will be able to prevent the production of several pro-inflammatory mediators. ${ }^{21}$ The acute toxicity test of "meniran" leaves was carried out in vivo using ethanol as a solvent and gave a toxicity value of $\mathrm{LD}_{50}>5000 \mathrm{mg} / \mathrm{kgBW}$ and is included in the category of mild toxic. ${ }^{33}$

\section{Antitussive Activity}

1. "Takokak" (Solanum torvum Swartz.) is a plant that belongs to the Solanaceae family. The test was carried out by the induction method which was given citric acid to cause cough in guinea pigs. "Takokak" leaves methanol extract at a dose of 1000 $\mathrm{mg} / \mathrm{kgBW}$ showed a significantly different cough inhibition compared to the control group $(p<0.001)$ with an average percentage of cough inhibition of $73.63 \%$ which was comparable to the positive control given dihydrocodeine with an average the 
percentage of cough inhibition was $76.20 \%$. The content of compounds contained in "takokak" leaves are alkaloids, flavonoids, saponins, tannins, and glycosides. ${ }^{22}$ Toxicity testing was carried out using the Miller and Trainter method using a hydroalcoholic solvent which was tested on albino rats. The administration of the extract at a dose of $200 \mathrm{mg} / \mathrm{kgBW}$ did not show any toxic effects on the organs of the test animals. The dosing showed a change in the regeneration of $\mathrm{CCl} 4$-induced liver tissue. The extract effectively prevented hepatotoxicity. ${ }^{34}$

2. "Meniran" (Phyllanthus niruri L.) has been used for a long time because empirically it has efficacy in treating coughs. The "meniran" herb extract was tested using the in vivo method which was induced by $7.5 \%$ citric acid in order to give the guinea pig a coughing effect. Observations were seen from the number of coughs when induction was given up to 5 days after induction and "meniran" herbal extracts. The results showed a significant difference $(p<0.05)$ in the negative control group and the 125 $\mathrm{mg} / \mathrm{kgBW}$ ethanol extract group against the $250 \mathrm{mg} / \mathrm{kgBW}$ ethanol extract group and the polar - semi-polar 80 fraction group; $160 \mathrm{mg} / \mathrm{kgBW}$. The polar - semi-polar fraction group of $160 \mathrm{mg} / \mathrm{kgBW}$ gave the most effective antitussive activity seen from its antitussive value of $65.87 \%$ compared to other solvents, while the positive control with $10 \mathrm{mg} / \mathrm{kgBW}$ of codeine gave a $71.67 \%$ reduction in cough. The content of compounds in "meniran" herbs are flavonoids, quercetin, astragaline, and xylan. Quercetin has a good IC50 value in inhibiting hexosaminidase in RBL-2H3 cells so that it has anti-allergic activity. Astragalin works in inhibiting the production of IL-4 and IL-13 so that it has anti-allergic activity. ${ }^{21}$ Toxicity testing was carried out using water solvent, where the test animals when given the "meniran" herb water extract at a dose of $5000 \mathrm{mg} / \mathrm{kgBW}$ did not show any significant changes compared to the normal group in the levels of bilirubin, total protein, albumin, globulin, urea, creatinine, hemoglobin; the activity of ALT, AST, ALP, GGT enzymes; and complete blood count. Acute toxicity tests resulted in $L_{50}$ values $>5000 \mathrm{mg} / \mathrm{kgBW}$ and is included in the category of mild toxic. ${ }^{33}$

\section{Antipyretics Activity}

1. "Belimbing wuluh" (Averrhoa bilimbi L.) is a plant that belongs to the Oxalidaceae family. The antipyretic activity was carried out using the in vivo method by measuring the rectal temperature of the rats every 30 minutes for 360 minutes that induced by DPT vaccine and treated with extracts. The results showed that the temperature of test groups were lower than rats rectal temperature that were induced by the DPT vaccine. Various doses of ethanol extract of "belimbing wuluh" fruit that were tested on rats at a dose of $1.75 \mathrm{~g} / \mathrm{kgBW}$ showed a decrease in temperature. This shows that the use of DPT vaccine induction can increase the rectal temperature of rats and the ethanol extract of "belimbing wuluh" fruit has an antipyretic activity which is effective in lowering the body temperature of rats with fever with a decrease in body temperature of $22.9 \%$ while the decrease in body temperature of the group of rats given aspirin $0.004 \mathrm{~g} / \mathrm{kgBW}$ was $27.8 \%$. The compounds contained in "belimbing wuluh" fruit were alkaloids, flavonoids, and saponins. Alkaloids have the effect of reducing fever, relieving pain, sedation and diuretic. Flavonoids are compounds that have effects as antihypertensive, anti-inflammatory, antibacterial, antipyretic, diuretic, and dilatation of capillary blood vessels. When the body is infected with microorganisms, saponins will work by inhibiting the binding of exogenous pyrogens to their receptors so that the body does not have a fever. Alkaloid and flavonoid compounds work by inhibiting the cyclooxygenase I enzyme pathway so that it will inhibit the formation of pain mediators (prostaglandin) or inhibit the increase in body temperature. ${ }^{23}$ 
2. "Wualae" plant (Etlingera elatior (Jack) R. M. Smith) belongs to the Zingiberaceae family. Testing of the ethanolic extract of the "wualae" fruits as an antipyretic was carried out using the in vivo method which was induced by the DPT vaccine to increase body temperature in mice. The administration of ethanol extract of "wualae" fruit at a dose of $400 \mathrm{mg} / \mathrm{kgBW}$ showed a decrease in body temperature of $90 \%$ while the decrease in body temperature using Paracetamol $1.3 \mathrm{mg} / \mathrm{kgBW}$ was $91.9 \%$. This shows that the ethanolic extract of the "wualae" fruits has antipyretic activity because it can lower the body temperature of mice and has a percentage of antipyretic power that is almost comparable to the positive control. The compounds contained in "wualae" fruits was flavonoids which can inhibit the cyclooxygenase I pathway so that prostaglandins are not formed and cause the effect of decreasing body temperature and decreasing inflammation. ${ }^{24}$ The acute toxicity test of ethanol extracts of "wualae" fruit was carried out using the Reed-Munch method, while the toxicity value obtained was $L D_{50}=8649,679 \mathrm{mg} / \mathrm{kgBW}$ (practically non-toxic). ${ }^{35}$

3. Basil (Ocimum basilicum L.) apart from being used as a food ingredient, it is also used as a medicinal plant. Basil is a plant that belongs to the Lamiaceae family. Basil seed testing was carried out using the in vivo method with $12.5 \%$ peptone induction using a solvent consisting of $10 \%$ ethanol, $10 \%$ ethyl acetate and, $10 \%$ n-hexane which gave a significant difference $(p<0.05)$ to control. The use of ethyl acetate solvent showed a greater decrease in body temperature compared to other solvents, namely $1.7^{\circ} \mathrm{C}$. This shows that the ethyl acetate extract of basil seeds has antipyretic activity because it provides the most effective effect compared to other solvents in lowering body temperature with a decrease in body temperature of $88.23 \%$ while a decrease in body temperature for comparison is $91.9 \%$. The content of compounds in basil seeds are flavonoids that work as cyclooxygenase inhibitors, which could inhibit the formation of pain mediators in the form of prostaglandins, causing the effect of lowering body temperature. ${ }^{25}$ The acute toxicity test of Basil seeds was carried out using the OECD 420 fixed-dose procedure method using a hydrogel solvent produced by basil seeds. The test results obtained $L_{50}$ value $=9000$ $\mathrm{mg} / \mathrm{kgBW}$ and is included in the category of practically non-toxic. ${ }^{36}$

\section{Analgetics Activity}

1. "Meniran" (Phyllanthus niruri L.) has been widely used empirically in treating cough, fever, vomiting blood, diabetes, rheumatism, and so on. "Meniran" is a plant that belongs to the Phyllanthaceae family. Testing of the ethanol extract of the leaves of "meniran" (Phyllanthus niruri L.) was carried out to determine the analgesic activity by using the writhing method by induction in the form of $1 \%$ acetic acid to male mice. The test results of the ethanol extract of "meniran" leaves at a dose of 100,200, and $400 \mathrm{mg} / \mathrm{kgBW}$ showed analgesic activity as seen from the number of writhing of male mice. The percent of protective power at doses of 100,200 and $400 \mathrm{mg} / \mathrm{kgBW}$, were 73.56 ; 82.61 ; and $96.02 \%$ respectively. The extracts at all test doses showed analgesic effect which was comparable to the positive control given ibuprofen with a percentage of the protective power of $76.82 \%$. The greater the dose of ethanol extract of "meniran" leaves used, the greater the analgesic power obtained. ${ }^{26}$

2. "Sembukan" (Paederia foetida L.) is a plant that belongs to the Rubiaceae family heal empirically because it has properties like analgesic, anti-rheumatic, smooth urination, anti-inflammatory, cough medicine, and so on. The ethanol extract of the "sembukan" leaves was tested using the writhing test method on mice induced by $0.5 \%$ acetic acid. Observations were seen from the number of writhing of mice and the percentage of protection against various doses of the ethanol extract of the "sembukan" leaves used. The test results of negative control, positive control and ethanol extract of the leaves of heal at a dose of 80,160 , and $320 \mathrm{mg} / \mathrm{kgBW}$ gave 
significant results $(p<0.05)$ on the average number of stretches, while the LSD test results for protection power between groups had a significantly different percentage of protective power compared to the negative control. This shows that the positive control group and the test group have the ability as an analgesic. The percentage of protective power of ethanol extract at a dose of $80 \mathrm{mg} / \mathrm{kgBW}$ is $35.18 \%$; the dose of $160 \mathrm{mg} / \mathrm{kgBW}$ was $53.58 \%$ and the dose of $320 \mathrm{mg} / \mathrm{kgBW}$ was $68.98 \%$ while the percentage of the protective power of positive control given by diclofenac potassium was $39.18 \%$. This shows that the ethanol extract at a dose of $320 \mathrm{mg} / \mathrm{kgBW}$ provides analgesic activity with a decrease in the average number of writhing and the percentage of the protective power that is more effective than other doses. The content of compounds contained in "sembukan" leaves consists of flavonoids, steroids, tannins, and saponins. ${ }^{27}$ Toxicity testing of the ethanol extract of the "sembukan" leaves was carried out using the OECD 423 method and obtained a toxicity value of $L D_{50}>2000-5000 \mathrm{mg} / \mathrm{kgBW}$ and is included in the category of mild toxic. ${ }^{37}$

3. Papaya (Carica papaya L.) is empirically used to treat various types of diseases such as pain, relieving pain, shedding menstruation, increasing appetite, worming, malaria fever, and so on. Papaya belongs to the Caricaceae family. Testing of papaya leaves ethanol extract was carried out to determine the analgesic activity using the writhing test method. The test was carried out by dividing the group into a negative control group, a positive control group, and a test group with ethanol extract of papaya leaves at doses of 100,300 , and $600 \mathrm{mg} / \mathrm{kgBW}$. One-way ANOVA statistical test showed that the positive control group and the test group showed a significant compared to negative control difference $(p<0.05)$. The ethanol extract of papaya leaves at doses of 300 and $600 \mathrm{mg} / \mathrm{kgBW}$ gave analgesic activity by reducing the number of writhing. The extract at doses of 300 and $600 \mathrm{mg} / \mathrm{kgBW}$ gives percent protection power of $48.73 \%$; and $59.94 \%$ respectively while the percent protection power of Paracetamol at a dose of $65 \mathrm{mg} / \mathrm{kgBW}$ is $80 \%$. The ethanol extract of Papaya leaves at a dose of $600 \mathrm{mg} / \mathrm{kgBW}$ has better analgesic activity than a dose of $300 \mathrm{mg} / \mathrm{kgBW}$. Papaya leaves contain flavonoids that work by inhibiting the cyclooxygenase I enzyme which produces prostaglandins as pain mediators, when COXI is inhibited, pain mediators will not be formed or inhibit the formation of prostaglandins so that they will not cause pain. In addition, papaya leaves have papain enzymes which have analgesic and anti-inflammatory activities that can reduce the amount of stretching of the test animals. ${ }^{28}$ The acute toxicity test on Papaya leaves methanol extract was carried out in vivo and obtained a toxicity value of $L D_{50}>1000 \mathrm{mg} / \mathrm{kgBW}$ and is included in the category of mild toxic. ${ }^{38}$

\section{Anti-allergic Activity}

1. The anti-allergic effect testing of guava leaves ethanol extract was carried out by giving ovalbumin as an inductor. Observations were seen from the average number of scratching rats that experienced a decrease in allergic reactions due to ovalbumin induction and were given guava leaves ethanol extract with various doses. The test results of guava leaves ethanol extract gave statistically significant results because it was able to suppress allergic reactions by reducing the average number of scratching rats compared to the negative control group $(p<0.05)$. The ethanol extract at a dose of 27,54 , and $108 \mathrm{mg} / 200 \mathrm{gBW}$ gave an average amount of stretching of 17.50; 9.00; and 15.25 times respectively, while the positive control was given methylprednisolone at a dose of $0.072 \mathrm{mg} / 200 \mathrm{BW}$ gave an average amount of stretch of 2.25 time. The anti-allergic effect decreased at a dose of $108 \mathrm{mg} / 200 \mathrm{gBW}$, which was indicated by a higher average number of scratching rats. According to the receptor occupancy theory, the maximum effect of the drug will occur if all the 
receptors have been occupied by the drug so that an excess dose of a drug can cause the formation of free drugs. If the free drug accumulates a lot in the body, it will result in a decrease in the effect of the drug and even toxicity. The content of compounds contained in the ethanol extract of guava leaves is quercetin, where quercetin is one of the flavonoid compounds that have anti-allergic activity through the mast cell stabilization mechanism which will inhibit the release of histamine. In addition, quercetin can reduce the average number of scratching mice given ovalbumin induction. ${ }^{29}$. The acute toxicity test on guava leaves water extract was carried out using the in vivo method with the $\mathrm{LD}_{50}$ value $>5000 \mathrm{mg} / \mathrm{kgBW}$ and is included in the category of mild toxic. ${ }^{39}$

\section{Conclusion}

It can be concluded that of the 196 plants used empirically in the treatment of colds, a total of 5 plants have been tested for expectorant activity, 2 plants have been tested for antitussive activity, 3 plants have been tested for antipyretic activity, 3 plants have been tested for analgesic activity and 1 plant has been tested for activity anti-allergic. According to the test, 10 plants that have been tested for acute toxicity test. "Meniran" (Pyllantus niruri L.) was the best herb to treat common cold because its proven to have expectorant, antitussive, analgesic effects and have been tested for acute toxicity test.

\section{Acknowledgement} review.

Thank you to those who have helped and supported the preparation of this article

\section{References}

1. Setyopuspito, Pramitaningastuti A. Uji efektivitas antiinflamasi ekstrak etanol daun srikaya (Annona squamosa. L) terhadap edema kaki tikus putih jantan galur wistar. Jllm Farm. 2017;13(1):8-14.

2. Mulyani Y, Sumarna R, Patonah. Kajian etnofarmakologi pemanfaatan tanaman obat oleh masyarakat di Kecamatan Dawuan Kabupaten Subang Provinsi Jawa Barat. J Farm Galen (Galenika J Pharmacy). 2020;6(1):37-54.

3. Amin M, Perawati S, Sutrisno D. Etnofarmasi pada suku anak dalam di Desa Pauh Menang Kecamatan Pamenang. J Heal Technol Med. 2020;6(1):334-44.

4. Hermin H, Ibrahim N, Nugrahani A. Kajian etnofarmasi etnik Bungku di Kecamatan Bungku Tengah Kabupaten Morowali Provinsi Sulawesi Tengah. J Farm Galen (Galenika J Pharmacy). 2016;2(2):76-82.

5. Maftuchah $M$, Christine $P$, Jamaluddin $M$. The effectiveness of tea tree oil and eucalyptus oil aromaterapy for toddlers with common cold. J Kebidanan. 2020;10(2):131-7.

6. Papas D. Principles and practice of pediatric infectious diseases. Elsevier Public Heal Emerg Collect 1st ed. 2018. p. 199-202. Available from: https://www.ncbi.nlm.nih.gov/pmc/articles/PMC7152197/

7. Simasek M, Blandino D. Treatment of common cold. Am Fam Physician. 2007;75(4):515-20. Available from: www.aafp.org/afp

8. Kesehatan K, RI. Hasil utama riset kesehatan dasar 2018. 2018.

9. Nurlela L, Harfika M. Air rebusan belimbing wuluh sebagai antitussive dan expectorant pada ISPA. J IIm Keperawatan. 2019;14(2):50-60.

10. Asridawati I, Perawati S. Studi etnofarmasi pada Suku Anak Dalam (SAD) di Desa Semambu Kecamatan Sumay Kabupaten Tebo Provinsi Jambi. J Indones. 
2020;17(1):172-86.

Available

from:

http://jurnalnasional.ump.ac.id/index.php/PHARMACY/article/view/6938

11. Sastroanidjojo D. Obat asli Indonesia. 1948.

12. Mardisiswojo S. Cabe puyang warisan nenek moyang III. Jakarta: PN BALAI PUSTAKA; 1968.

13. Indonesia DK. Tanaman obat Indonesia. 1985.

14. Departemen Kesehatan Republik Indonesia. Materia medika Indonesia. 3rd ed. Jakarta; 1979. p. 15.

15. Islami M, Ibrahim N, Nugrahani A. Studi etnofarmasi suku Kaili Moma di Kecamatan Kulawi, Kabupaten Sigi, Provinsi Sulawesi Tengah. J Farm Galen (Galenika J Pharmacy). 2017;3(1):27-33.

16. Chevallier A. Encyclopedia of herbal medicine. In: 550 Herbs and Remedies for Common Ailments. 3rd ed. DK; 2016. 118, 157, 185 p.

17. Achmad S, Hakim E, Makmur L, Syah Y, Juliawaty L, Mujahidin D. Ilmu kimia dan kegunaan tumbuh-tumbuhan obat Indonesia. Ed 1st, editor. ITB; 2011.

18. Kurniati NF, Suwandi DW, Yuniati S. Aktivitas mukolitik kombinasi ekstrak etanol daun kemangi dan ekstrak etanol daun sirih merah. Tradit Med J. 2018;5(1):7-13.

19. Nerdy N, Manurung K. Mucolytic activity of roselle (Hibiscus sabdariffa L.) Calyces extract on cow intestinal mucus. J Kedokt Hewan - Indones J Vet Sci. 2018;12(2):43-6.

20. Pakadang S, Sinala S, Salasa A, Ratnah S, Rosmala Dewi S, Hilaria M. Potential of miana leaf extract as expectorant (profile place of growing, antioxidant, sputum contaminants, antibacterial, MIC, MKC expectorant). Maj Obat Tradis. 2020;25(2):94.

21. Nurrochmad A, W G. Aktivitas antitusif dan ekspektoran ekstrak etanol, fraksi polar-semi polar herba meniran (Phyllanthus niruri L.) pada marmut (Cavia porcellus). J Farm Indones. 2017;14(2):118-24.

22. Amponsaa Brobbey, A Kwarley Quartey A, Otuo-Serebour S, Ayensu I. Determination of the antimicrobial and antitussive activities of the leaves of solanum torvum. Planta Med. 2018;18(1):S1-381.

23. Andriyanto A, Isriyanthi N, Sastra E, Arif R, Mustika A, Manalu W. Aktivitas antipiretik ekstrak etanol buah belimbing wuluh (Averrhoa bilimbi) pada tikus putih jantan. J Vet. 2018;18(4):597.

24. Malik F, Ningsi A, Bafadal M, Saktiani D, Wahyuni W. Uji efek antipiretik ekstrak etanol buah wualae (Etlingera elatior (jack) R.M. Smith) terhadap mencit jantan (Mus musculus L.) galur balb/C. Pharmauho J Farm Sains, dan Kesehat. 2018;4(1):11-3.

25. Rahimah S, Hendrarti W, Ramlah S. Uji aktivitas ekstrak biji selasih (Ocimum basilicum L.) dengan beberapa pelarut sebagai antipiretik pada mencit (Mus musculus). J Ilm As-Syifaa. 2015;7(2):158-63.

26. Alyidrus R, Ariastiwi D, Mardi Y. Ekstrak etanol daun meniran (Phyllanthus niruri L.) terhadap mencit jantan (Mus musculus) yang diinduksi asam asetat sebagai analgetik. Media Farm. 2019;15(1):51.

27. Sentat T, Handayani F, Indaswari E. Uji aktivitas analgetik ekstrak etanol herba sembukan (Paederia foetida L.) pada mencit putih jantan (Mus musculus) yang diinduksi dengan asam asetat. J IIm Ibnu Sina. 2020;5(2):358-63.

28. Afrianti $R$, Yenti $R$, Meustika D. Analgesic activity of papaya leaf extract (Carica papaya L.) on male mice induced by Acetic Acid 1\%. J Sains Farm Klin. 2014;1(1):54-60.

29. Kawuri W, Yudhani R, Setyawan N. Efek antihistamin ekstrak daun jambu biji (Psidium guajava) pada tikus putih (Rattus norvegicus) dengan induksi ovalbumin. Smart Med J. 2019;2(1):18. 
30. Abrori C, Nurfadhila K, Nurus Sakinah E. Uji toksisitas akut ekstrak etanol daun kemangi diukur dari nilai LD50 dan histopatologi ginjal. Agromedicine Med Sci. 2015;5(1).

31. Sari F, Nurkhasanah, Bachri M. Acute toxicity test of rosella (Hibiscus sabdariffa L.) Calyx Ethanolic Extract on Sprague Dawley Rats. Tradit Med J. 2016;21(1):128.

32. Ridwan Y, Satrija F, Handharyani E. Toksisitas akut ekstrak daun miana (Coleus blumei benth) pada mencit (Mus musculus). Acta Vet Indones. 2020;8(1):55-61.

33. Asare G, Addo P, Bugyei K, Gyan B, Adjei S, Otu-Nyarko L. Acute toxicity studies of aqueous leaf extract of phyllanthus niruri. Interdiscip Toxicol. 2011;4(4):20610.

34. Bhuvaneswari T. Studies on the physico-phytochemical properties and hepatoprotective effect of solanum torvum swartz in CCl4 induced experimental toxicity in albino rats. Int J Pharm Pharm Sci. 2012;4:4-7.

35. Jabbar A, Wahyuni W, Yusuf M, Helmia W, Sahidin I. Uji toksisitas akut ekstrak etanol buah wualae (Etlingera elatior (Jack) R. M. Smith) terhadap gambaran histopatologi organ jantung tikus wistar (Rattus norvegicus). Pharmauho J Farm Sains, dan Kesehat. 2020;54(3-4):291-9.

36. Lodhi BA, Hussain MA, Ashraf MU, Farid-UI-Haq M, Haseeb MT, Tabassum TS review/mukolitik/uji toksistas/UT ADK (Ocimumsanctum). pd. Acute Toxicity of A Polysaccharide-based Hydrogel from Seeds of Ocimum basilicum. Cellul Chem Technol. 2020;54(3-4):291-9.

37. Fitriana I, Wijayanti AD, Puspa Wikan Sari R, Gagak Donny S D. Toksisitas akut ekstrak sembukan (Paederia scandens (Lour.) Merr.) pada mencit (Mus musculus L.) galur swiss. J Farm Indones. 2016;13(1):12-21.

38. Santi T. Uji toksisitas akut dan efek antiinflamasi ekstrak metanol dan ekstrak nheksana daun pepaya (Carica papaya L.). Pharm Sci Res. 2015;2(2):101-14.

39. Enechi O, Tufon E, Ogugua V. Toxicological studies of aqueous leaf extract of mucuna pruriens on albino rats. Res J Pharmacol Pharmacodyn. 2011;3(5):2535. 